\author{
Agnieszka Izdebska \\ Katedra Teorii Literatury \\ Wydział Filologiczny \\ Uniwersytet Łódzki \\ e-mail: agnieszka.izdebska@uni.lodz.pl \\ ORCID: 0000-0002-6253-8397
}

\title{
Rola przestrzeni przedstawionej w powieści nowelowej
}

Bogumiła Kaniewska rozpoczyna swój artykuł Między cyklem a powieścia następującą uwagą: „Próba opisania relacji między cyklem utworów narracyjnych [...] a polską powieścią współczesną wydaje się przedsięwzięciem z góry skazanym na niepowodzenie" ${ }^{1}$. Z dalszych wyjaśnień wynika, że kłopoty te są raczej generalne, nie dotyczą wyłącznie literatury polskiej i mają swoje źródła w trzech kwestiach: braku systematycznych badań nad konwencją cyklu², przynależności cyklu do form gatunkowo „niepewnych” (bo jest „równocześnie całością i zbiorem całostek, tekstem i szeregiem tekstów, podwójnie delimitowanych" ${ }^{3}$ ) oraz pogłębiającej się nieoczywistości statusu gatunku powieściowego, rozsadzanego przez różne gatunki i genry mowy ${ }^{4}$.

Mimo tej dość pesymistycznej konstatacji, zamierzam poświęcić swój tekst formie, którą Krystyna Jakowska określiła terminem powieść nowelowa, pisząc: „[n]a styku cyklu opowiadań i powieści wytworzyła się hybrydyczna forma «powieści nowelowej» - tekstu, który może być czytany

1 B. Kaniewska, Między cyklem a powieścia, w: Cykl literacki w Polsce, red. K. Jakowska, B. Olech i K. Sokołowska, Białystok 2001, s. 23.

2 Tamże.

3 Tamże.

4 Tamże, s. 24. 
jako powieść lub jako cykl opowiadan'" 5 . Zanim przejdę do skrótowego - ze względu na temat i objętość tego artykułu - opisu zjawiska kryjącego się pod tym terminem, wyjaśnię, dość oczywiste, powody, dla których warto podjąć taką próbę. Otóż, określenie, czy ma się do czynienia z tekstem ciągłym, linearnym, czy też takim, na który składają się samodzielne całości, określa strategię lektury ${ }^{6}$. Ta zaś ma też swój wymiar komunikacyjno-etyczny: rozpoznanie genologicznego splotu uwikłań pewnych tekstów powinno je uwolnić od nieuzasadnionych czytelniczych i krytycznych oczekiwań - nie można bowiem wymagać, by teksty spełniały normy konwencji, których respektowanie nie było intencją autorów.

Teoretycznym punktem wyjścia do analiz wybranych utworów będą dla mnie, przede wszystkim, ustalenia pojawiające się w przywołanych już tekstach Jakowskiej i Kaniewskiej oraz rozważania Elke D’hoker zawarte w jej artykule A Continuum of Fragmentation. Distinguishing the Short Story Cycle from Composite Novel $^{7}$. O ile Kaniewska uważa, że „relacja między powieścią a cyklem nie sprowadza się do wpływu jednej formy na drugą - należałoby tu mówić o pewnym obszarze wspólnym, o sferze wspólnych możliwości, z których oba gatunki korzystają w równym stopniu" ${ }^{8}$, o tyle Jakowska uznaje, że powstanie polskiej powieści nowelowej w okresie międzywojennym było wynikiem ekspansji cyklu narracyjnego ${ }^{9}$. Z kolei D’hoker podkreśla konieczność uwzględnienia wpływu poetyki cyklu opowiadań na omawiane przez nią powieści określane jako composite novels ${ }^{10}$. Formę tę definiuje jako tekst fikcjonalny składający się z kilku odrębnych tekstów narracyjnych, opowieści połączonych za pomocą wzajemnych odwołań, tematycznych powiązań i świata przedstawionego. Tego rodzaju utwory charakteryzuje dynamiczne napięcie pomiędzy całością a ich częściami, które czyni z nich teksty otwarte, wymagające aktywności czytelnika w konstytuowaniu estetycznej i narracyjnej spójności. $W$ ten sposób zajmuje ona obszar graniczny między cyklem opowiadań a powieścią skonstruowaną jako narracja o losach jednego protagonisty, jednak ciągle w obrębie gatunku powieściowego ${ }^{11}$.

5 K. Jakowska, O cyklu opowiadań. Z teorii i historii cyklu narracyjnego w Polsce, Białystok 2011.

6 B. Kaniewska, Między cyklem a powieściq, s. 26.

7 E. D'hoker, A Continuum of Fragmentation. Distinguishing the Short Story Cycle from Composite Novel, in Constructing Coherence in the British Short Story Cycle, Londyn 2018, s. 17-31. Lista tekstów teoretycznych mogłaby być dłuższa, jednak sama D’hoker dokonuje rekapitulacji tez zawartych $\mathrm{w}$ anglo- i francuskojęzycznych rozprawach poświęconych cyklom opowiadań i formom $z$ nimi genologicznie spokrewnionym.

8 B. Kaniewska, Między cyklem a powieścia, s. 35.

9 K. Jakowska, O cyklu opowiadań, s. 148.

10 E. D'hoker, A Continuum of Fragmentation, s. 25.

11 Tamże, s. 28. 
Zdecydowałam się na potrzeby tego artykułu zapożyczyć od Krystyny Jakowskiej termin "powieść nowelowa”, jednak robię to z ogromną ostrożnością i głównie dla jego walorów językowych. Inny możliwy: „powieść w formie zbioru opowiadań", jest nieporęczny, nadto opisowy, wreszcie sugeruje, że składające się na taką całość poszczególne części mają mniej lub bardziej zamkniętą formę gatunkową - opowiadania właśnie, podczas gdy często bywają raczej szkicami czy fragmentami ${ }^{12}$. Nawiasem, to ostatnie zastrzeżenie odnosi się również do terminu Jakowskiej - bowiem „nowelowość” zakłada istnienie mocniejszych rygorów kompozycyjnych niż bardzo pojemny termin "opowiadanie". Z kolei tłumaczenie na polski określenia composite novel (funkcjonującego $\mathrm{w}$ anglojęzycznym literaturoznawstwie choćby w przywoływanym już tu użyciu D’hoker) jako „powieści kompozytowej” zdaje się nas odsyłać do świata materiałów budowlanych, terytorium dla literaturoznawcy jednak obcego. Kolejny możliwy wariant terminologiczny to „powieść amalgamatowa", choć i on nie wydaje mi się satysfakcjonujący. Ostatecznie zatem posługuję się tu terminem "powieść nowelowa”, jednak z zasadniczym, poza wymienionymi już powyżej szczegółowymi ${ }^{13}$, zastrzeżeniem: $\mathrm{w}$ przeciwieństwie do Jakowskiej, uważam, że teksty tak określane należy czytać jako powieści. Zatem, ostatecznie decyduję się na rozwiązanie hybrydyczne: przyjmuję termin Jakowskiej, ale samo pojęcie powieści nowelowej definiuję za D'hoker. Wypada jeszcze dodać, że moje rozpoznania mają w tym tekście charakter wstępny, przede wszystkim ze względu na ograniczenia redaktorskie i obszerność koniecznych do uwzględnienia literaturoznawczych kontekstów.

Przy analizowaniu tej formy gatunkowej może pojawić się pytanie, czy jest ona szczególnie funkcjonalna przy prezentacji określonej tematyki, czy jest jakoś semantycznie nacechowana. W przywoływanym tu już artykule Elke D'hoker sugeruje, że większość analizowanych przez nią powieści eksponuje napięcie między tym, co indywidualne, a tym, co zbiorowe, tym, co unikalne, a tym, co powtarzalne i typowe. Zdaniem badaczki to napięcie bywa wydobywane poprzez eksponowanie wspólnego miejsca fabuły: ulicy, przedmieść, wioski, miasta ${ }^{14}$. Z kolei Jakowska uważa, że „rola przestrzeni jako zwornika cykliczności jest spora, prawie żadna zaś - jako elementu po-

\footnotetext{
12 Tamże, s. 24.

13 Tu można jeszcze dorzucić kwestię materiału, którego analiza doprowadziła Jakowską do przywoływanych rozpoznań: są to polskie utwory wydane głównie w okresie międzywojennym i w perspektywie historycznoliterackiej przez nią lokowane. Mnie zaś będą interesować głównie teksty powstałe $\mathrm{w}$ kręgu angielskojęzycznym w drugiej połowie XX i w pierwszej dekadzie XXI wieku.

14 E. D'hoker, A Continuum of Fragmentation, s. 23.
} 
rządkującego”. I dodaje: „najczęściej tożsamość przestrzeni jest prostą funkcją jednorodności świata przedstawionego" ${ }^{\prime 15}$. Ja jednak chciałabym przyjrzeć się tu takim powieściom nowelowym, w których przestrzeń spełnia nie tylko funkcję porządkującą, ale stanowi także istotny, choć nieoczywisty, przedmiot przedstawienia. Przywoływane przeze mnie teksty to Arlington Park autorstwa Rachel Cusk ${ }^{16}$, kolejny to Hotel Świat Ali Smith ${ }^{17}$, wreszcie ostatni to Dziewczęta i kobiety Alice Munro ${ }^{18}$. Utwory te są różnie skonstruowane i różnie klasyfikowane: dwa pierwsze jako powieści, zaś ostatni z nich niektórzy krytycy nazywają powieścią ${ }^{19}$ lub tekstem hybrydycznym, mogącym być jako powieść postrzeganym ${ }^{20}$.

Arlington Park to utwór, który wydaje się idealnie wpisywać w definicję D’hoker (autorka pisze zresztą o tej powieści) i jest znakomitą ilustracją funkcji, jaką badaczka przypisuje przestrzeni przedstawionej w omawianych przez nią tekstach. Tom zaczyna się od bardzo wyrazistego określenia miejsca akcji: „W Arlington Park padało całą noc” [s. 7]. I dalej:

Deszcz padał na kręte średniowieczne uliczki, brudne wiktoriańskie zaułki i szerokie, zbombardowane niegdyś ulice, przy których dzisiaj pobudowano centra handlowe. Zalewał szpital, stary teatr i nowy multipleks. [...] Na Arlington Rise deszcz spływał ze wzgórza rynsztokami [...]. W miarę, jak droga pięła się ku Arlington Park, zuchwałe wielkie magazyny ustępowały miejsca kwiaciarniom i antykwariatom, sklepy monopolowe zastąpiły składy win, a fast foody - bistra. Jak okiem sięgnąć, wzdłuż drogi wyłaniało się coraz więcej drzew, w deszczu nadając okolicy jakiś rys antyczny. [...] Padało tak do świtu, gdy raptem, ze wzmożoną siłą, nad domami przetoczyła się kaskada wody, zalewając ciemne jeszcze okna. Uśpieni w łóżkach ludzie nagle usłyszeli tę ogłuszającą nawałę. Przeniknęła ich sny niczym gromki aplauz niewidzialnej publiczności. [...] Było tak, jakby ktoś ich obserwował, jak gdyby dokoła zebrali się widzowie, zaglądając w ciemne okna, klaszcząc w ręce [s. 9-12]

15 K. Jakowska, O cyklu opowiadań, s. 27.

16 R. Cusk, Arlington Park, przeł. P. Łopatka, Kraków 2010. Wszystkie cytaty w tekście za tym wydaniem.

17 A. Smith, Hotel Świat, przeł. A. Lakatos, Warszawa 2002. Wszystkie cytaty w tekście za tym wydaniem.

18 A. Munro, Dziezwczęta i kobiety, przeł. P. Łopatka, Warszawa 2013. Wszystkie cytaty w tekście za tym wydaniem.

19 Zob. np. D. Filipczak, Inteligentna i urodziwa w łożu Prokrusta: Del Jordan wobec konstrukcji kobiecości w powieści „Dziewczęta i kobiety”, w: Alice Munro. Wprowadzenie do twórczości, red. M. Buchholtz, Torun 2015, s. 62.

20 Zob. np.: E. Bodal, Alice Munro. Rys biograficzny, w: Alice Munro. Wprowadzenie do twórczości, s. 22; M. Redekop, Mothers and Other clowns. The Stories of Alice Munro, London \& New York, 1992, s. xi; P. Seyersted, "Who Do You Think You Are?" Alice Munro and the Place of Origin, „American Studies in Scandinavia” 1992, Vol. 24, s. 17. 
$\mathrm{W}$ tym obszernym fragmencie mamy do czynienia nie tylko $\mathrm{z}$ rozbudowaną deskrypcją, ale i z ustanowieniem perspektywy, z której ta opowieść będzie nam prezentowana. To perspektywa ustanawiająca swoisty dystans między metaforycznie traktowanymi widownią i sceną. Zdaniem Elke D’hoker to właśnie tak skonstruowany punkt widzenia, który określa jako spojrzenie ,z lotu ptaka", ustanowiony w ramie narracyjnej oraz przestrzeń przedstawiona stanowiąca coś więcej niż tło dla kontrapunktowo zestawionych losów postaci decydują o spójności, czytaj: powieściowości dzieła Cusk ${ }^{21}$. Rzeczywiście - autorka prezentuje kilka mieszkanek Arlington Park, najczęściej parę godzin z ich życia, niepełny, deszczowy dzień wypełniony zwykłą krzątaniną pań domu. Wspólnym mianownikiem tych historii zdaje się głębokie poczucie niespełnienia towarzyszące mieszkankom tego eleganckiego brytyjskiego przedmieścia. Ponadto protagoniści powieści Cusk mają stosunek emocjonalny do miejsca, w którym żyją, miejsca będącego tu niemal ekstraktem społecznego zjawiska "suberbii”. Niektórzy czują się uwięzieni w tej przestrzeni, obwiniają się wzajemnie o decyzje przeprowadzki z Londynu „na to zielone, powolne, senne przedmieście" [s. 231 ${ }^{22}$. Dla innych stanowi ona realizację marzenia o życiowym awansie.

Owo poczucie, że w Arlington Park opowiada się z owej „ptasiej” perspektywy tyleż o ludziach, co i o miejscach, wzmacnia umieszczony prawie centralnie fragment poświęcony parkowi pokazanemu w momencie, gdy ustaje deszcz, w którym Arlington Park moknie od świtu: „[p]rzez cały dzień park był pusty, zapomniany $\mathrm{w}$ deszczu, lecz teraz znowu pojawili się $\mathrm{w}$ nim ludzie. Wyłaniając się z aut i domów, z ulic i bocznych uliczek, przemierzali alejki zdecydowanym krokiem" [s. 184]. Co charakterystyczne, to "jacyś" ludzie: "Jakiś chłopiec wywrócił się na trocinach koło huśtawki i wstał zaryczany" [s. 188], "Jakiś chłopiec kopnął patyk w stronę siostry [...]" [s. 189], „[p]rzed nimi szły matki, rozmawiając" [s. 189], „[p]rzemknęła grupa ludzi w białych butach" [s. 191]. W środku tego opisu z ogromną mocą pojawia się owa dystansująca perspektywa, z której przechadzający się po parku mieszkańcy przedmieść oglądani są jako pionki uwięzione w porządku, na który nie mają wpływu:

21 E. D'hoker, A Continuum of Fragmentation, s. 23.

${ }^{22}$ Nie bez powodu krytycy wskazują na powinowactwa z pisarstwem Virginii Woolf, szczególnie z Paniq Dalloway. Zob. np. J. Lasdum, Disparate houswives, „The Guardian” 16.09.2006, https://www.theguardian.com/books/2006/sep/16/featuresreviews.guardianreview6 [dostęp 6.11.2020]. 
Cały ten rozpędzony ziemski mechanizm działał jak maszyna; czas, wpływając weń jak rzeka pozbawiona wody, wprawiał w ruch nawet najdrobniejsze tryby. Patrzenie na to sprawiało dziwny ból, udrękę. Stojące w trocinach kobiety zostały jakby usidlone, uwięzły $\mathrm{w}$ tej maszynerii. Utkwiły gdzieś między bezwodną rzeką a spienionymi kołami. W tej pułapce każdy ruch sprawiał ból. Raniły je pikujące z góry latawce. Ludzie w białych butach zdawali się po nich deptać. [...] Kobiety mogły znieść tylko te wiecznie rozkołysane huśtawki [s. 192].

Przestrzeń zdaje się tu nie tylko całkowicie determinować ludzkie losy, zachowania, nawyki, ale i tworzyć labiryntową pułapkę, w której ruch jest pozorny, a zmiana niemożliwa.

Zatem, jeśli przestrzeń przedstawiona stanowi tu jeden z zasadniczych elementów skłaniających do lektury tego tekstu złożonego z odrębnych opowieści jako całości wymagającej scalającej interpretacji, to jest to raczej przestrzeń przedstawiana nie jako realna geograficznie, ale jako pewien stan umysłu bohaterów. Arlington Park jako miejsce jest owego stanu przestrzenną emanacją.

Hotel Świat Ali Smith to powieść, którą D’hoker określa jako „wielogłosową" ${ }^{23}$. Składa się na nią sześć monologów wewnętrznych kobiet, które w rozmaity sposób związane są z tytułowym hotelem. Pierwsza z nich, pracująca w nim, popełnia tam samobójstwo, druga jest bezdomną zaproszoną przez recepcjonistkę do spędzenia w jednym z pokoi mroźnej nocy, kolejna to owa recepcjonistka, która zapada na poważną chorobę i nie jest pewna, czy wróci do hotelu. Czwarta to dziennikarka recenzująca brytyjskie hotelarstwo, która natyka się na dziwaczną postać na hotelowym korytarzu. Opowieść domykają perspektywy dwóch postaci: siostry samobójczyni, Sary Wilby, myszkującej w hotelu, by odkryć, jak wyglądała ostatnia droga Sary (to ją spotyka dziennikarka) i "dziewczyny ze sklepu z zegarkami”, która nosi jej zegarek, fantazjując, jak to będzie, gdy ta kiedyś się po niego zgłosi:

Każdego ranka, zapinając pasek myśli o tym samym. To właśnie dziś. Oprze nagie nadgarstki o ladę i powie: Przyszłam po odbiór zegarka na nazwisko Wilby. Dziewczyna ze sklepu z zegarkami pokaże jej zegarek na swoim nadgarstku. Mam nadzieję, że nie ma pani nic przeciwko temu, powie. Jakoś mi się spodobał [s. 201-202].

23 Zestawianie, jak to czyni D'hoker, utworu Smith z Kiedy umieram Wiliama Faulknera wydaje się tu nieporozumieniem, choć rzeczywiście autorka posługuje się w swojej powieści konwencją bezpośredniego monologu wewnętrznego. Powieść Faulknera skonstruowana jest wokół wyraziście zarysowanych perypetii fabularnych, u Smith takich powiązań nie ma. Zob. D’hoker, A Continuum of Fragmentation, s. 26. 
Zatem to Sara jest postacią, której losy tworzą ramę powieści - w finale poznamy przedmiot jej fascynacji, dziewczynę, która nigdy się o owej fascynacji nie dowie i nie przypuszcza, że właścicielka zegarka nigdy się po niego nie zgłosi.

Tytuł powieści Smith sugeruje, że właśnie to miejsce - hotel-świat - stanowi centrum, wokół którego toczy się tu opowieść - jakkolwiek byłaby ona, jako składająca się z monologów wewnętrznych, fragmentaryczna i niespójna. Wszystkie postaci pojawiające się $\mathrm{w}$ hotelu-świecie mają do niego różny stosunek - jest on dla nich ekwiwalentem domu, chwilową przystanią, miejscem pracy, przestrzenią skrywającą zagadkę czyjejś tragicznej śmierci. Nawet jeśli o tym nie wiedzą, jak ostatnia z bohaterek powieści, ich los jest z Hotelem spleciony ${ }^{24}$.

Jednym z elementów nadającym spójność składającemu się z fragmentów Hotelowi Światu jest ta sama, otwierająca i kończąca tekst fraza: „Uuuuuuuuu-huuuuuuuu”. To okrzyk Sary spadającej w luku windy towarowej. Kiedy otwiera powieść, następuje po nim anons: „[o]to moja opowieść. Zaczyna się od końca. Spadłam w środku lata, na drzewach były liście. Teraz jest środek zimy (liście dawno opadły) i to by było na tyle, dziś moja ostatnia noc, tej nocy niczego bardziej nie pragnę, niż mieć w bucie kamyk" [s. 11]. Taki początek sugeruje, że reszta tekstu tworzy jakąś całościową opowieść, zapewne achronologiczną i nieco oniryczną - wszak pierwszoosobowa narratorka jest $\mathrm{w}$ niedookreślonym ontologicznie stanie - ale jednak spójną. Ta zakładana koherencja wydaje się być wzmacniana tytułami poszczególnych części nadającymi całości również porządek czasowy. Mamy zatem Czas przeszły, Czas teraźniejszy miniony, Czas przyszły warunkowy, Czas perfekt, Czas przyszły miniony, Czas teraźniejszy. Tłumaczka usiłowała tu oddać nie do końca czytelny dla polskiego odbiorcy nieznającego języka angielskiego kontekst gramatyczny. W oryginale owe tytuły brzmią odpowiednio: Past, Present Historic, Future Conditional, Perfect, Future in the Past i Present ${ }^{25}$. Zatem opowieści Smith porządek narracyjny nadaje ta, niejako zewnętrzna, konstrukcja. Co ciekawe, w polskim tłumaczeniu powieści wydawcy zdecydowali się na umieszczenie spisu treści nieistniejącego $\mathrm{w}$ oryginale. Taki zabieg eksponuje porządek opowieści jako zbudowany na następstwie względnie autonomicznych części.

24 Kompletnie inaczej interpretuje tę powieść Alicia J. Rouverol w swoim tekście Fragmentary writing and globalization in Ali Smith's "Hotel World", czytając ją jako opowieść o lęku przed globalizującym się światem. Polemika ze stanowiskiem autorki lub też jego akceptacja wymagałaby właściwie napisania odrębnego tekstu, więc pomijam tę kwestię, odnotowując ją tylko przypisowo. Niemniej, jak widać, powieść Smith prowokuje do rozlicznych interpretacji i literaturoznawczych dysput.

25 A. Smith, Hotel World, London 2002. 
Hotel $\mathrm{w}$ powieści Smith to jeden z budynków światowej sieci, pełen przykurzonych wykładzin i tanich tapet. Gmach będący wiernym powieleniem wszystkich innych o tej nazwie, o takim samym wystroju i projekcie, bez względu na to, czy stoją w Kairze, Brighton czy Madrycie. W tej przestrzeni i w relacji z nią, doskonale anonimową, nie-domową, dokonują się losy protagonistek, osobne i powiązane zarazem.

Konstrukcja przestrzeni w utworach Alice Munro to kwestia dość złożona - nie inaczej jest też w wydanym w 1971 roku tomie Dziewczęta $i$ kobiety. Merilyn Simonds w tekście Where do you think you are. Place in the short stories of Alice Munro ${ }^{26}$ wykazuje, że opowieści Munro pozornie osadzone są w konkretnych miejscach geograficznych, najczęściej w małych miasteczkach południowo-zachodniego Ontario. Ta nieoczywistość lokacji nie wynika oczywiście z tego, że nazw tych miejsc nie ma na mapie Kanady, ale z tego, że owe nazwy nie mają specjalnego znaczenia. Bez wdawania się tu w szczegółowy opis tez Simonds sformułowanych na podstawie przekonujących analiz wypada za nią powtórzyć, że w utworach Munro elementem kreacji świata przedstawionego jako miejsca niepewnego i nieoczywistego jest takaż przestrzeń $^{27}$. W rezultacie, zdaniem Simonds, w opowieściach pisarki nigdy nie wiemy dokładnie, gdzie jesteśmy i na co patrzymy ${ }^{28}$. Ostatecznie stałym elementem we wszystkich tekstach Munro jest zmaganie się protagonistek z poczuciem przynależności do jakiegoś miejsca i jednocześnie chęć uwolnienia się od niego ${ }^{29}$.

W poszczególnych częściach tomu Dziewczęta $i$ kobiety zdarzenia opisywane są w trybie narracji pierwszoosobowej. Główna bohaterka, Del Jordan, sama opowiada historię swoją, matki i innych mieszkańców Jubilee. Munro operuje tu wąskim horyzontem czasowym narracji. Poszczególne części tomu są zamknięte nie tylko fabularnie, ale i kompozycyjnie ${ }^{30}$. Niektóre z nich kończy wyrazista koda, puenta, zdanie będące tyleż podsumowaniem przedstawionych zdarzeń, co niedopowiedzianą, zaskakującą i przewrotną ich inter-

\footnotetext{
26 To oczywiste nawiązanie do kolejnego „powieściopodobnego" tekstu kanadyjskiej pisarki, What do you think you are. W polskim tłumaczeniu tom nosi tytuł Za kogo ty się uważasz.

27 M. Simonds, Where do you think you are. Place in the short stories of Alice Munro, w: The Cambridge Companion to Alice Munro, ed. D. Stains, Cambridge 2016, s. 36.

28 Tamże, s. 38.

29 Tamże, s. 42.

30 Sama Munro określała ją jako episodic novel [zob. W. R. Martin, Alice Munro. Paradox and Parallel, Edmonton 1987, s. 75]. Martin komentuje kłopoty z genologiczną klasyfikacją Dziewwcząt $i$ kobiet oraz Za kogo ty się uważasz jako istotne dla unikania szufladkowania pisarki jako operującej wyłącznie krótkimi formami narracyjnymi [tamże, s. 75-76].
} 
pretacją ${ }^{31}$. Ostatnie opowiadanie Dziewczęta $i$ kobiety ma tytuł Epilog. Fotograf - co zdaje się podkreślać "powieściowe” intencje autorki. Sugeruje bowiem istnienie jakiejś całościowej historii, której zamknięcie ma stanowić dopiero ów ostatni fragment. Co więcej, skłania czytelnika do reinterpretacji całości: wszak dopiero w Epilogu Del objawia nam się jako przyszła pisarka ${ }^{32}$. Zatem finał ma nieco Proustowski wymiar - Del podejmuje decyzję o pisaniu powieści, jak chcą niektórzy krytycy, tej, którą właśnie kończymy czytaćc ${ }^{33}$. $\mathrm{W}$ pewnym sensie mamy tu zatem do czynienia z konwencją Künstlerroman - opowieścią o dojrzewaniu artysty.

Wracając jednak do kwestii roli przestrzeni przedstawionej w Dziewczętach $i$ kobietach i tez Simonds: Jubilee, miasteczko, do którego przeprowadza się bohaterka, to miejsce o bardzo silnej społecznej stratyfikacji. Matka dziewczynki uważa te przenosiny za awans społeczny, wiążący się z porzuceniem dotychczasowego miejsca zamieszkania, specyficznego "pomiędzy” miastem a wsią, nieszczęsnej Drogi na Moczary. Del docenia uroki miasta:

lubiłam ład, harmonię, zawiły porządek miejskiego życia, dostrzegalny jedynie dla przybysza z zewnątrz. Wracając ze szkoły [...] napawałam się atmosferą miasteczka, ulicami o nazwach takich jak Rzeczna, Kamieniarska, [...] Wiktorii [...] i - ciekawa rzecz - Chartumska [s. 105].

Jednak to samo miasteczko widziane przez okno samochodu, gdy dziewczynka jedzie z nowo objawionym bratem matki po zakupy do sklepu kolonialnego, zmienia swoje oblicze: „Jubilee nie wydawało się wyjątkowe i stałe

31 Na przykład opowiadanie Następcy żywego ciała - w finale tekstu bohaterka znajduje w swojej piwnicy, po powodzi, całkowicie zniszczone zapiski wuja, przekazane jej przez jego siostry z nadzieją, że będzie je kontynuowała i wyda - zamyka zdanie: „Przypomniało mi się, jak odprowadzały wzrokiem rękopis, gdy opuszczał ich dom w pudle zamkniętym na kłódkę, i poczułam skruchę, tę wątłą skruchę, której towarzyszy okrutna, niezmącona satysfakcja" [s. 93].

32 Munro wyznała w rozmowie z J.R. Struthersem, że póki nie zamknęła całego tomu ostatnim opowiadaniem, całość była historią dorastania jakiejś dziewczyny - potem stała się opowieścią o stawaniu się pisarką: „Up until now this was not the story of the artist as a young girl. It was just the story of a young girl. And this introduced a whole new element, which I felt had not been sufficiently prepared for. And yet, I found eventually that the book didn't mean anything to me without it" [J.R. (Tim) Struthers, The Real Material: An Interview with Alice Munro, w: Probable Fictions: Alice Munro's Narrative Acts, ed. L.K. McKendrick, Toronto 1983, s. 25, cyt. za C. A. Howells, Alice Munro, Manchester \& New York: Manchester University Press, 1998, s. s. 33].

33 R. Fowler, The Art of Alice Munro: "The Begger Maid" and "Lives of Girls and Women", "Critique" 1984, Vol. 25, No. 4, s. 197, cyt. za B. Kucała, W stronę literatury: "Dziewczęta i kobiety”, w: Alice Munro. Wprowadzenie do twórczości, red. M. Buchholtz, Toruń 2015, s. 79. Teza ta wydaje mi się jednak nieco dyskusyjna. 
jak dotąd, lecz dziwnie prowizoryczne i nędzne, wprost żałosne" [s. 124]. Kolejnej metamorfozie miejska przestrzeń ulegnie w zamyśle pierwszej powieści Del:

Na potrzeby powieści zmieniłam Jubilee, a ściślej wybrałam pewne jego cechy, odrzucając inne. Moje miasteczko było starsze, mroczniejsze, mocno zapuszczone, pełne niemalowanych drewnianych płotów pokrytych wystrzępionymi plakatami cyrków, jesiennych festynów, wyborów, o których dawno zapomniano. [...] wszystko jawiło mi się jako prawdziwe, nie realne tylko prawdziwe, tak jakbym odkrywała - nie tworzyła - tych ludzi i tę historię, jak gdyby to miasteczko istniało obok tego, z którym obcowałam co dnia [s. 342].

W finale, opisując spotkanie $z$ dziwacznym Bobby'm Sheriffem (to dzieje jego rodziny chciała uczynić osią fabuły swej powieści), Del mówi:

Życie w Jubilee jak wszędzie było nudne, banalne, zdumiewające i niepojęte - głębokie pieczary wyłożone linoleum. Nie przypuszczałam, że kiedyś będę go tak złakniona. Że zapragnę spisać wszystko [...]. Sporządzałam rozmaite listy. Spis wszystkich sklepów i firm przy głównej ulicy, łącznie z właścicielami. Spis rodów, nazwisk na nagrobkach na cmentarzu i inskrypcji pod nimi [...] I żadna lista nie objęłaby tego, na czym mi zależało, bo zależało mi na najdrobniejszych szczegółach, na każdym słowie, zdaniu, myśli, najmniejszej smużce światła, jak musnęła korę albo ścianę, każdym zapachu, wyboju, bólu, rysie i złudzeniu. Bo chciałam uchwycić to wszystko i połączyć w spójną promienną całość. Na zawsze [s. 349].

Jubilee zatem stanie się miejscem, które bohaterka opuści, a jednocześnie poniesie w sobie jako cenny, choć ambiwalentny dar. Zdekonstruuje je i skonstruuje ponownie $\mathrm{w}$ fikcji, powieli $\mathrm{w}$ wielu wersjach. Może też dlatego, że miasteczko jest przestrzenią tyleż realną, co mentalną, płynną, niestabilną, bo zależną od tego, jak w danej chwili jawi się obserwatorowi. I dlatego podlegającą wiecznej metamorfozie ${ }^{34}$.

Podsumowując te rozważania o roli przestrzeni przedstawionej $\mathrm{w}$ formie nazwanej tu wstępnie powieścią nowelową, należy stwierdzić, że owa przestrzeń, nawet użyta w uspójniającej całość funkcji jest bardzo mocno konstruowana, nie pojawia się jako quasi-realna i ulokowana geograficznie. Zawsze jest waloryzowana, metaforyzowana i nieoczywista. Zatem to wspólne miejsce fabuły - przynajmniej $\mathrm{w}$ analizowanych przeze mnie tu tekstach -

34 Zob. A. Izdebska, W Kanadzie, w domu, w kuchni, na linoleum - o opowiadaniach Alice Munro, „Białostockie Studia Literaturoznawcze” 2015, nr 6. 
nie jest „przezroczystym” czy „mechanicznym” elementem uspójniającym te opowieści, ale jednym $\mathrm{z}$ wielu domagających się interpretacji aspektów procesu konstytuującego całość tak skonstruowanych powieści.

\section{Bibliografia}

Bodal Ewa (2015), Alice Munro. Rys biograficzny, w: Alice Munro. Wprowadzenie do twórczości, red. M. Buchholtz, Toruń: Wydawnictwo Adam Marszałek, s. 19-29. Constructing Coherence in the British Short Story Cycle (2018), ed. P. Gill \& F. Kläger, London: Routledge.

Cusk Rachel (2010), Arlington Park, przeł. P. Łopatka, Kraków: Wydawnictwo Literackie.

D'hoker Elke (2018), A Continuum of Fragmentation. Distinguishing the Short Story Cycle from Composite Novel, in Constructing Coherence in the British Short Story Cycle, ed. P. Gill \& F. Kläger, London: Routledge, s. 17-31.

Dunn Maggie, Morris Ann (1995), The Composite Novel. The Short Story Cycle in Transition, New York: Twayne Publishers.

Filipczak Dorota (2015), Inteligentna i urodziwa w tożu Prokrusta: Del Jordan wobec konstrukcji kobiecości w powieści "Dziewczęta i kobiety”, w: Alice Munro. Wprowadzenie do twórczości, red. M. Buchholtz, Torun: Wydawnictwo Adam Marszałek, s. $61-73$.

Guignery Vanessa, Drąg Wojciech [eds] (2019), The Poetics of Fragmentation in Contemporary British and American Fiction, Deleware: Vernon Press, s. 67-80.

Howells Coral Ann (1998), Alice Munro, Manchester \& New York: Manchester University Press.

Izdebska Agnieszka (2015), W Kanadzie, w domu, w kuchni, na linoleum - o opowiadaniach Alice Munro, „Białostockie Studia Literaturoznawcze”, nr 6, 83-98.

Jakowska Krystyna (1993), Delimitacja tekstu w cyklu opowiadan, „Pamiętnik Literacki”, nr 2, s. 94-106.

Jakowska Krystyna (2011), O cyklu opowiadań. Z teorii i historii cyklu narracyjnego w Polsce, Białystok: Wydawnictwo Uniwersyteckie Trans Humana.

Jakowska Krystyna, Olech Barbara, Sokołowska Katarzyna [red.] (2001), Cykl literacki $w$ Polsce, Białystok: Wydawnictwo Uniwersytetu w Białymstoku.

Kaniewska Bogusława (2001), Między cyklem a powieścia, w: Cykl literacki w Polsce, red. K. Jakowska, B. Olech i K. Sokołowska, Białystok: Wydawnictwo Uniwersytetu w Białymstoku, s. 23-35.

Kieżuń Anna, Kulesza Dariusz [red.] (2010), Cykle i cykliczność. Prace dedykowane Pani Profesor Krystynie Jakowskiej, Białystok: Trans Humana.

Kucała Bożena (2015), W stronę literatury: „Dziewczęta i kobiety”, w: Alice Munro. Wprowadzenie do twórczości, red. M. Buchholtz, Toruń: Wydawnictwo Adam Marszalek, s. 75-89.

Lasdum James (2006), Disparate houswives, „The Guardian” 16.09, https://www.the guardian.com/books/2006/sep/16/featuresreviews.guardianreview6 [dostęp 6.11.2020]. 
Malicka Patrycja (2017), Badanie nad cyklem literackim w Polsce, „Forum Poetyki” jesień (10), s. 140-145.

Martin W.R. (1987), Alice Munro. Paradox and Parallel, Edmonton: The University of Alberta Press.

Modern American Short Story Sequences. Composite Fictions and Fictive Communities (1995), ed. J. G. Kennedy, Cambridge: Cambridge University Press.

Munro Alice (2013), Dziewczęta i kobiety, przeł. P. Łopatka, Warszawa: Wydawnictwo W.A.B.

Redekop Magdalene (1992), Mothers and Other Clowns. The Stories of Alice Munro, London and New York: Rutladge.

Rouverol Alicia J. (2019), Fragmentary writing and globalization in Ali Smith's "Hotel World", w: The Poetics of Fragmentation in Contemporary British and American Fiction, ed. V. Guignery i W. Drąg, Deleware: Vernon Press, s. 67-80.

Seyersted Per (1992), "Who Do You Think You Are?" Alice Munro and the Place of Origin, "American Studies in Scandinavia”, Vol. 24, s. 17-23.

Simonds Merilyn (2016), Where do you think you are. Place in the short stories of Alice Munro, w: The Cambridge Companion to Alice Munro, ed. D. Stains, Cambridge: Cambridge University Press, s. 26-44.

Smith Ali (2002), Hotel World, London: Penguin Books.

Smith Ali, (2007), Hotel Świat, przeł. A. Lakatos, Warszawa: Warszawskie Wydawnictwo Literackie MUZA SA.

\title{
The Role of the Presented Space in the Novella Novel
}

\begin{abstract}
This article focuses on outlining the function of the presented space in the novella novel as an element constituting its coherence. The term "novella novel" (adopted from Krystyna Jakowska and defined by Elke D'hoker) refers to literary works that are generically situated between a coherently composed collection of short stories and a loose novelistic structure. The following works will serve as the material for the analysis: Arlington Park by Rachel Cusk, Hotel World by Ali Smith and Girls and Women by Alice Munro. These pieces are structured and classified differently. The former two are referred to as novels, while the latter one is called by some critics a novel or a hybrid text that can be perceived as a novel. Ultimately, although sometimes used as an element that maintains coherence, the presented space is always meticulously crafted, and it does not appear as quasi-real or geographically located. It is always valorised, metaphorized and ambiguous. Thus, such a common setting is not a "transparent" or "mechanical" element that unifies these stories, but rather one of the many aspects of the process that constitutes coherence of novels constructed in such a way, which remains open to interpretation.
\end{abstract}

Keywords: composite novel, novella novel, narrative cycle, presented space 